\title{
LEGISLATIVE SUPPORT FOR EXPANDING THE LAND POWERS OF LOCAL SELF- GOVERNMENT BODIES IN UKRAINE
}

\author{
aOleksii Yu. Piddubnyi*, bLiudmyla D. Rudenko, aLiusia V. Hbur, cValentyna V. Nezhevelo, aViktoriia P. Oleksiuk \\ ${ }^{a}$ National University of Life and Environmental Sciences of Ukraine, Kyiv, Ukraine \\ ${ }^{b}$ Sumy State University, Sumy, Ukraine \\ cSumy National Agrarian University, Sumy, Ukraine.
}

\section{ARTICLE INFO}

\section{Article History}

Received: April 21, 2021

Revised: July 1, 2021

Accepted: July 30, 2021

\section{Keywords}

Land relations

European integration

Regionalization

Decentralization

Natural resources

\section{A B S T R A C T}

The relevance of this study is conditioned by the implementation of the reform in the context of the decentralisation of power in Ukraine, the aspirations of Ukraine for European integration and the movement for the creation of a "Europe of Regions". The purpose of the study is to comprehensively investigate the legislative support for expanding the land powers of local self-government bodies in Ukraine in the context of the movement for the creation of a "Europe of Regions" based on the analysis of scientific opinions, generalisation of the provisions of Ukrainian legislation and positive experience of other countries. Universal methods were used in the study: dialectical, empirical, and logical. The general scientific methods of cognition used in this study include analysis and synthesis, generalisation, modelling, etc. In addition, the study applied the following special legal methods: conceptual legal, comparative legal, formal legal, etc. The leading method in the study was the comparative legal method. It helped compare the specific features of the practice of other countries in the field of legislative support for the expansion of land powers of local self-government bodies, as well as identify how this issue is regulated in different countries of the continental model of the land management system. Information and knowledge from different countries can be used as a basis for the adoption, adaptation, and development of new relevant provisions in Ukraine. Based on the legislation on local self-government and land legislation, the study analysed the main powers of local self-government bodies in the management of land relations. The experience of the land management system in developed countries is studied considering the movement for the creation of a "Europe of Regions", focusing the research on the continental model of the land management system.

Corresponding Author: Oleksii Yu. Piddubnyi

Email: o-yu-piddubnyi6777@national-univesity.info

(C) The Author(s) 2021.

\section{INTRODUCTION}

Land has always been and will always be the main asset and the basis for the well-being and life of the population. Ukraine has enormous land assets. Agricultural land of Ukraine is 41.4 million hectares, which is approximately $70 \%$ of the total fund of Ukraine. Therewith, the amount of land per person in Ukraine is
0.9 hectares, while in Europe, this figure reaches 0.44 hectares ${ }^{1}$.

${ }^{1}$ Land directory of Ukraine. 2020. https://agropolit.com/storage/2020/Zemelniy_dovidny k_2020.pdf?utm_source $=$ mailchimp\&utm_campaign $=03$ 00ccc2e1fo\&utm_medium=page 
In this context, agricultural land determines the importance of these lands, both for the development of national specialisation and gross national product, and in the overall work on the protection of the state's land fund and its effective use. At the same time, land relations are one of the most important aspects of the multifaceted architecture of the legal system of Ukraine. Notably, in the process of land relations management and control over the intended use of agricultural land, an important role currently belongs to local selfgovernment bodies, which necessitates a separate study on specification of their goals, tasks, and principles of land relations management at the level of local selfgovernment bodies in this area.

The Constitution of Ukraine (1996) ${ }^{2}$ declares that land is the main national wealth of Ukraine, which is under special state protection (Plotnikova, 2017). Within the limits of the powers granted by law, local selfgovernment bodies carry out organisational and administrative activities that require consistent, coordinated legal separate actions - administrative procedures, accompanied by various legal means of a statutory, administrative, and jurisdictional (law enforcement) nature in the field of land relations (Kyrychenko, 2020). The problem of decision-making of local self-government bodies in the field of land relations, as well as legislative support for the expansion of land powers of local self-government bodies in Ukraine, is critical given the reform in the context of the decentralisation of power in Ukraine, the aspirations of Ukraine for European integration and the movement for the creation of a "Europe of Regions". In addition, at the international level, the decentralisation of public power is considered as one of the key elements of the public administration system reform and is a priority area of activity of international and national organisations. Therewith, one of the most important tasks to date is to support local self-government and create conditions for sustainable and independent development of territorial communities.

Considering the above, ensuring the rational use and management of land resources certainly implies the existence of a well-established functioning of local self-

${ }^{2}$ Constitution of Ukraine. 1996.

https://zakon.rada.gov.ua/laws/show/254к/96вр\#Text government bodies in the field of land relations. As Kravchenko (2015) notes, local self-government bodies can quickly and effectively implement national land policy at the local level to ensure the effective and rational use of land resources by all subjects of land use relations based on their equal access to the exercise of relevant rights. At the same time, the main areas of organising land relations in localities should include consistency of interests between private, public, and state entities; transparency in the use and distribution of land; guarantee of rights to land; reliability of restrictions on the use of land plots; stability of land use types; the ability to determine the most appropriate use of land by the owner or user of the land plot (Strokan, 2009). In this context, there is currently no doubt that each object of municipal property is a component of an economic system built on special subject-object relations and provided with appropriate forms of management. However, the system-forming object of municipal ownership is land, which ensures the development of all spheres of economic and social life of the local community. Land and land relations have always been the determining factors of the country's socio-economic development. That is why the policy of local selfgovernment bodies on land management should ensure openness, transparency, clarity, objectivity, and fairness of land use.

The purpose of the study is to comprehensively investigate the legislative support for expanding the land powers of local self-government bodies in Ukraine in the context of the movement for the creation of a "Europe of Regions" based on the analysis of scientific opinions, generalisation of the provisions of Ukrainian legislation and positive experience of other countries.

\section{MATERIALS AND METHODS}

$A$ set of various general scientific techniques and methods was applied for a comprehensive analysis of the subject under study. In particular, universal methods were used in the study: dialectical, empirical, and logical. For example, using the dialectical method, new results were found, that is, the study transformed pre-created theoretical knowledge in the field of legislative support for the expansion of land powers of local selfgovernment bodies and by systematically adding new theoretical provisions, new modifications of existing knowledge were developed. The general scientific methods of cognition used in this study include analysis 
and synthesis, generalisation, modelling, etc. Thus, for the purpose of a comprehensive study of the subject, the study used the method of system analysis and synthesis, which helped identify the main features of legislative support for the expansion of land powers of local selfgovernment bodies.

In addition, the study applied the following special legal methods: conceptual legal, comparative legal, formal legal, etc. At the same time, the comparative legal method was the leading method in the study. It helped compare the specific features of the practice of other countries in the field of legislative support for the expansion of land powers of local self-government bodies, as well as identify how this issue is regulated in different countries. Information and knowledge from different countries can be used as a basis for the adoption, adaptation, and development of new relevant provisions. The work also used system-structural, integrated, and holistic research approaches. The formulation and justification of theoretical provisions, proposals for improving legislation, practical recommendations and conclusions are performed based on the above methods and approaches. Therewith, the use of various methods and approaches in their combination allowed solving the research tasks set. The regulatory framework of the study included the Constitution of Ukraine, the land legislation of Ukraine and legislation regulating the activities of local selfgovernment bodies, as well as foreign land legislation.

The empirical framework of the study included statistical and analytical data on the state, use, protection, turnover of land in the process of implementing land reform, law enforcement practice in this area, materials of judicial practice, etc. Methodological foundations of the study of nature, genesis and consistency, structure and functions, modelling methods and algorithms for improving land relations have been studied by many scientists. The conclusions put forward in this study are based on the synthesis of methodological approaches and theoretical solutions proposed in the studies by many scientists, including: Ignatenko (2018); Kravchenko (2015); Kuz (2019); Kyrychenko (2020); Miroshnichenko and Marusenko. (2009); Monastyrskyy (2002); Shulha and Ihnatenko. (2016); Slipetska (2015); Strokan (2009, 2010), and other scientists. Despite the broad theoretical development of this problem, the study of the methodological basis for the development of land relations and their regulation, the problem still requires the continuation of research. In particular, for the development of land transformations, it is necessary to expand research on legal, economic, organisational, and technical issues of this problem, the place and role of land relations in the system of public relations. Issues of legislative support for expanding the land powers of local self-government bodies in Ukraine in the context of the movement for the creation of a "Europe of Regions" require a more thorough justification.

\section{RESULTS}

The entry into force of the Association Agreement between Ukraine, of the one part, and the European Union, the European atomic energy community and their member states, of the other part $(2015)^{3}$ in 2017 entails updating the issue of legislative support for the expansion of land powers of local self-government bodies in Ukraine in the context of the movement for the creation of a "Europe of Regions". In particular, Article 446 of the Association Agreement between Ukraine, of the one part, and the European Union, the European atomic energy community and their member states, of the other part (2015) determines that "the parties promote mutual understanding and bilateral cooperation in the field of regional policy regarding the methods of forming and implementing regional policies, in particular multi-level management and partnership, with special emphasis on the development of backward territories and territorial cooperation, while creating communication channels and enhancing the exchange of information between national, regional, and local authorities, socio-economic entities and representatives of civil society." As Slipetska (2015) notes, the concept of Europe of Regions aims to determine the place of regions in the European (EU). Acting as a kind of scheme within which it is necessary to overcome the "localist" philosophy, as well as, on the other hand, the idea of hegemony of the national state and government, the concept of Europe of Regions is currently becoming increasingly important. In this context, the regions of the

${ }^{3}$ Association Agreement between Ukraine, of the one part, and the European Union, the European atomic energy community and their member states, of the other part.

2015.

https://zakon.rada.gov.ua/laws/show/984_011\#Text 
European Union, as well as the associated phenomenon of regionalisation, are strategic tools that design and create a new Europe adapted for further economic and political integration.

There are three concepts of the phenomenon of Europe of Regions: given the discrepancy with modern realities, the national state will gradually disappear, and supranational and regional unified European levels will be formed; close interregional economic cooperation and interaction of regions in a common economic space will lead to the "fusion" of Europe; "three-stage" Europe: the European Union, national states, national regions (Kuz, 2019). In this context, the authors of this study agree with Kurylyak (2018), which defines the overall concept of the European Union's regional policy "Europe of Regions" as a phenomenon that has expanded at different stages of development to supplement the elements that were necessary due to the growing maturity of regional relations and changes in the national and global environment. The concept of Europe of Regions has become widespread for the settlement of the entire system of relations, where the EU regions or the entire EU are represented in a global environment. However, it is also used in a different meaning within the community, for example, as a tool of the European Commission in the confrontation with the Council of Ministers to expand its competence and national governments to strengthen their requests for increased European funding for their territories. Therewith, the concept of Europe of Regions is fundamental in aspects of the regional policy of the European Union regarding subnational entities and in the geopolitical aspect.

In addition, the general principle of law, such as the transfer of power to the level of local self-government bodies, which is proclaimed by the European Union, and also stipulated in the European Charter of Local Government $(1985)^{4}$, is becoming increasingly widespread in the Member States of the European Union. In this context, the main principle that gives the right to make decisions at the level of local selfgovernment bodies, including on land issues, is the principle of subsidiarity, which makes provision for leaving only those functions at the state level that cannot be resolved by local self-government bodies. That is why it is possible to increase the competitiveness of regions

4 European Charter of local government. 1985. https://zakon.rada.gov.ua/laws/show/994_036\#Text by making structural changes in the economy, which would include ensuring the expansion of land powers of local self-government bodies. Therewith, land relations, as a complex aggregate of interaction between subjects of land ownership rights regarding its possession, use, and disposal as a limited natural resource, means of production, property and goods, are decisive in the entire system of agrarian transformations. Thus, local self-government bodies possess, use, and dispose of municipal land and other natural resources to develop the municipality and secure the socio-economic interests of its citizens.

To date, there are a considerable number of regulations governing land relations in Ukraine. In particular, the legislative consolidation of land powers of local selfgovernment bodies in Ukraine is reflected in the Land Code of Ukraine $(2001)^{5}$, the Law of Ukraine No. 280/97-VR "On Local Self-Government in Ukraine" (1997)6, the Law of Ukraine No. 858-IV "On Land Management" (2003), the Law of Ukraine No. 3613-VI "On the State Land Cadastre" (2011)7, the Law of Ukraine No. 962-IV "On Land Protection" (2003) Law of Ukraine No. 963-IV "On State Control over Land Use and Protection" (2003) ${ }^{9}$. Thus, according to the legislation of Ukraine, the main subjects of land relations management are local self-government bodies (Strokan, 2010). Article 19 of the Constitution of Ukraine (1996) stipulates that the Constitution of Ukraine and the laws of Ukraine establish the limits of powers of local selfgovernment bodies, their officials, who are obliged to act exclusively based on the legislation of Ukraine. This means that local self-government bodies take compliance with the requirements of the current legislation into consideration upon decision-making (Samorodov, 2016). Notably, the powers of village, town,

${ }^{5}$ Land code of $\quad$ Ukraine. 2001. https://zakon.rada.gov.ua/laws/show/2768-14\#Text

${ }^{6}$ Law of Ukraine No. 280/97-VR "On Local SelfGovernment in Ukraine". 1997. https://zakon.rada.gov.ua/laws/show/280/97-вр\#Tех

${ }^{7}$ Law of Ukraine No. 3613-VI "On the State Land Cadastre". 2011. https://zakon.rada.gov.ua/laws/show/3613-17\#Text ${ }^{8}$ Law of Ukraine No. 858-IV "On Land Management". $2003 . \quad$ https://zakon.rada.gov.ua/laws/show/858$15 \#$ Text

${ }^{9}$ Law of Ukraine No. 962-IV “On Land Protection”. 2003. https://zakon.rada.gov.ua/laws/show/962-15\#Text 
and city councils in land relations are stipulated in the Land Code of Ukraine (2001). In particular, Article 12 thereof stipulates that said councils can dispose of the lands of a territorial community; transfer land plots that are in communal ownership to the ownership of citizens and legal entities; withdraw land plots from communal ownership lands; responding to public needs, they can buy out the land plots of the respective communities; organise land management; coordinate the activities of local land resources bodies; monitor compliance with legislation in the field of ecology and land use.

In case of violation of legislation in the field of ecology and land use, these councils can restrict or introduce a temporary ban on the use of land by citizens and legal entities; prepare conclusions on the withdrawal of land plots; establish and change the boundaries of settlements; make proposals to the district council on establishing and changing the boundaries of villages, towns, cities; resolve land disputes; resolve other issues in the field of land relations. Therewith, the tasks of state monitoring of land use by controlled entities are consolidated in Chapter 32, Articles 187-190 of the Land Code of Ukraine (2001). Notably, the Law of Ukraine No. 280/97-VR "On Local Self-Government in Ukraine" (1997) regulates the competence of local selfgovernment bodies in the field of land relations. In particular, in accordance with Articles 26 and 33 of the said Law, the executive bodies of councils have the following powers in the field of land relations: to monitor compliance with legislation in the field of land use and protection; to register subjects of land ownership rights, land use rights, and land lease agreements; to issue documents certifying ownership and land use rights; to organise and maintain land cadastral documentation; to resolve land disputes, etc. At the same time, powers in the field of land relations cannot be transferred to any other local self-government body (or executive authority, municipal enterprise, institution, organisation) (Shulha and Ihnatenko., 2016). According to Decree of the President of Ukraine no. 449/202010 "On Some Measures to Accelerate Land Relations Reforms" (2020), agricultural land plots were

${ }^{10}$ Decree of the President of Ukraine No. 449/2020 “On some measures to accelerate reforms in the field of land relations". 2020. https://zakon.rada.gov.ua/laws/show/449/2020\#Text transferred to communal ownership. Therewith, the state-owned land plots are transferred to communal ownership by decision of executive authorities or local self-government bodies that dispose of land in accordance with the powers defined by the Land Code of Ukraine (2001). The general procedure for transferring land from state to municipal ownership is set out in Article 117 of the Land Code of Ukraine (2001). Furthermore, the fact of transfer of a land plot must be registered by the corresponding statement of transfer and acceptance, which is drawn up based on a decision of executive authorities or local self-government bodies on the transfer of a land plot to communal ownership.

\section{DISCUSSION}

Over the past 15 years, a number of political, economic, environmental, and social factors, as well as technological innovations, have profoundly changed the prospects for effective management of land, natural resources, and the environment in general. Security of ownership and registration of ownership ("property rights" should be considered in the broadest context, which encompass all human-land relations) are recognised as important components for achieving sustainable development in a global context, in particular considering the Sustainable Development Agenda until 2030 (Kalogianni et al., 2020). In almost all countries of the European Union, the constitution sets out the basic principles of regulating land and property relations. Strict conditions have also been introduced for the targeted use of land of various categories, considering the zoning of the settlement territory and the rules of land use and development, as well as compliance with the procedure for selling state land and buying land from individuals for state needs and national security. Furthermore, in most countries of the world, the fundamental principles of land management organisation are gathered in the land code, which forms the legal basis for regulation. However, in each country, the principles, approaches, methods, and forms of land management in the agricultural sector of the economy differ substantially.

Upon studying the experience of the land management system in developed countries, Lamert (2014) identifies two models of the land management system in a special group, namely: the Anglo-Saxon (American) model, which operates in the UK, USA, Canada, India, Australia, and New Zealand. This approach is described by a high 
degree of autonomy of local self-government, electability, control of citizens over it, the absence of local administrations in the form of state bodies, and the continental (European) model, which is common in continental Europe, in most countries of Latin America and the Middle East. Here, local self-government is combined with the presence of local administrations (public administration bodies at the local level); local self-government is included in the system of public administration; furthermore, this model is described by limited autonomy of local self-government. Considering the belonging of Ukraine to the continental model, the study analysed the experience of legislative support for land powers of local self-government bodies in other countries of the continental model of the land management system.

For example, in this context, Germany has a long tradition in local self-government. Today, the cornerstone of the institution of local self-government in Germany is reflected in the European Charter of Local Government (1985). Germany was one of the first countries to sign the European Charter of Local Government (1985), as its principles reflect and emphasise the current system of local self-government in Germany. Therefore, approaches and practices in various German lands offer a broad framework for studying the functioning of established local selfgovernment and its relations with state bodies (Ruge and Ritgen., 2021). Thus, in Germany, land ownership is protected by the Fundamental Law of the Federal Republic of Germany (1949) ${ }^{11}$. According to Article 14 of the Fundamental Law of the Federal Republic of Germany (1949), private property is guaranteed as a legal institution. Furthermore, German land law is governed mainly by Bürgerliches Gesetzbuch (1896) ${ }^{12}$, Gesetz über das Wohnungseigentum und das Dauerwohnrecht (1951) ${ }^{13}$, Gesetz über das Erbbaurecht (Erbbaurechtsgesetz - ErbbauRG) (1919) ${ }^{14}$ and

${ }^{11}$ Fundamental Law of the Federal Republic of Germany. 1949. https://www.bundestag.de/gg

12 Bürgerliches Gesetzbuch. 1896. https://www.gesetzeim-internet.de/bgb/

13 Gesetz über das Wohnungseigentum und das Dauerwohnrecht. 1951. https://www.gesetze-iminternet.de/woeigg/

14 Gesetz über das Erbbaurecht (Erbbaurechtsgesetz ErbbauRG). 1919. https://www.gesetze-iminternet.de/erbbauv/BJNR000720919.html
Grundbuchordnung (1897) ${ }^{15}$. Property and other real powers to land exist only if they are expressly stipulated by law. These powers include, in particular, right of ownership, right of development, pledge, easement, usufruct, right of residence. Initial information about the boundaries of the location and size of land plots and other real estate objects is contained in the acts of cadastral survey and accounting. Therewith, the cadastral bureau is within the authority of municipalities or local self-government bodies of the district. The task of the cadastral bureau is to provide plans that show all existing land plots.

In Germany, the fragmentation of agricultural land is legally prohibited, as well as alienation, which implies misuse of land. However, in Germany, persons engaged in agricultural production are allowed to purchase farmland based on an agreement, but persons who are not engaged in agricultural production are prohibited from purchasing it even for rent. Therefore, Germany has strict control over the rational use of agricultural land. Approximately the same order exists in Italy, Norway, Sweden, and France. In other words, these countries have strict requirements for the use of farmland in accordance with its intended purpose and the availability of professional knowledge in their owners. In Denmark, a farm that uses farmland exists as a family business. It is interesting that the maximum size of farms in Denmark is defined at the legislative level. For example, up to 150 hectares of agricultural land, with the requirement that the farmer (owner or tenant) has permanent residence in his or her own farm. In this country, a permit for large plots of land can be obtained if the farmer proves the need for additional land for agricultural production. Brazil disallows foreigners to own agricultural land (Rizokulov and Akbarzoda., 2020). Sweden and the Netherlands have national programmes aimed at full self-sufficiency in agricultural products. To achieve this goal, governments actively subsidise their farmers, compensating for interest on loans issued by commercial banks. In addition, Sweden and the Netherlands have special duties on food imports that protect the interests of national agricultural producers. The Swedish model of pension provision for farmers is of some interest. In 1979, a special fund was created in

15 Grundbuchordnung. 1897. https://www.gesetze-iminternet.de/gbo/BJNR001390897.html 
Sweden, the task of which is to purchase land from elderly Swedish farmers in exchange for pension provision. In France, most municipalities disallow the reduction of agricultural land to prevent the expansion of urban areas at the expense of farmland. If the land has not been cultivated for more than three years or the intensity of land use has led to a considerable deterioration in soil fertility, then the land, same as in Germany, can be forcibly withdrawn from the owners, but with mandatory monetary compensation for the value of the seized land, which is not the case in the German model. This provision is stipulated in the Code Civil (1804) ${ }^{16}$ of France. Therewith, high taxes from the sale of farmland are established in France to eliminate land speculation (Aytkhozhaeva, 2018). Notably, since local self-government is primarily responsible for ensuring the interests of citizens living within a certain locality, and not the interests of the state, it is necessary to expand the rights of local self-government and give them the appropriate powers to develop their own executive bodies, including in the field of land relations (Ignatenko, 2018).

Management of land relations by local self-government bodies presupposes compliance with the "five balances" rule:

1. The balance of interests of all stakeholders in determining, planning, in the process of achieving and evaluating results ("balance of interests of participants").

2. The balance of interests of present and future generations, advantages in the short and long term, improving the quality of life and investment in development ("balance from the time perspective").

3. The balance of expected results and available resources, which means compliance with the principles of ambition and achievement of goals and results, the ratio of the significance of results and the level of risks affecting the achievement of results; compliance with this rule involves the development of alternative options for achieving goals and obtaining results and selecting the best option from the available alternatives ("balance of results and limitations").

4. The balance of initiative and achievement assessment,

${ }^{16}$ Code civil. 1804. https://www.legifrance.gouv.fr/codes/id/LEGITEXT000 006070721/ that is, a combination of "proactive" approaches (implementing policies that consider development trends and possible risks based on "early warning systems" and other tools) and "reactive" approaches that involve evaluating virtual achievements and adjusting actions based on virtual results ("balance of initiatives and risks").

5. The balance of personal responsibility for the result and freedom of administration, which means the ability to manage internal risks upon considering (evaluating, predicting) external risks while maintaining responsibility for achieving the result, which is implemented through tools as an external and internal accountability for the result ("balance of freedom and responsibility") (Konstantinova, 2015).

In general, based on the above analysis, the use of the formed tools for land management used in the economy of individual countries of the world, considering the specific features of Ukraine, can enhance the mechanism for improving the efficiency of land resources use, as well as improve the scientific base in the aspect of improving the land management efficiency. In this aspect, the well-established practice of land management in developed countries is not only interesting, but also useful for expanding the land powers of local self-government bodies in Ukraine in the context of the movement for the creation of a "Europe of Regions". Therewith, the main purpose of municipal land resources management is to meet the needs of citizens through the use of beneficial properties of land resources. In turn, the said needs mean maintaining a high level of social, environmental, and economic conditions of society's life; stimulating the development of social, entrepreneurial, and other activities; restoring and preserving the properties of the natural environment in general and land resources in particular; creating socially and economically justified payments for land resources. In this context, Monastyrskyy (2002) believes that many factors influence the effectiveness of the realisation of the local self-government bodies' competence in control over land relations activities. In particular, the main factors are the as follows: thoroughness and integrity of land powers; transparency and clarity of regulatory formation of powers in the field of land relations; use of the granted powers in practice; resource content of the process of implementing powers, etc.

Therewith, Miroshnichenko and Marusenko. (2009) note 
that the policy of self-government bodies in control over the protection of land resources should preserve the soil and its useful properties, in particular, fertility, prevent the loss and depletion of agricultural land; timely prevent and eliminate the causes contributing to degradation, pollution, and littering of land, disruption and destruction of the soil, as well as impoverishment of the ecosystem; rational use and storage of resources, improvement of the useful properties and sanitary condition of soils; prevent the negative impact of degraded, polluted, and disrupted land on human health, individual natural resources and the environment in general, as well as on the economic and social development of the state; protect against unjustified withdrawal of land used by agriculture and forestry for non-agricultural needs. In conclusion, local selfgovernment bodies have a certain competence in land relations management, but in most cases the powers presented to them in this area do not give these bodies full power functions. In almost all functions of land relations management, the activities of local selfgovernment bodies are substantially limited by the powers of state authorities both in the field of land control and the exercise of the right of municipal ownership of land. Therewith, expanding the powers of local self-government bodies in this area, giving them more independence, would have a positive impact on the management of land relations, since local selfgovernment bodies are most "close to the people" and are more aware of problems in this area.

\section{CONCLUSIONS}

Legislation reform in the field of expanding the land powers of local self-government bodies in Ukraine in the context of the movement for the creation of a "Europe of Regions" remains a strategic task of Ukraine. Improvement of legislation in this area makes provision for amendments and additions to the legislation of Ukraine governing legal relations in the field of both local self-government and land relations. Such legislation should be aimed at simplifying the relevant administrative procedures and minimising the number of potential conflicts regarding the management of territories. In this context, it is also important to establish centres that would make effective decisions in the field of land relations at the local level. Local selfgovernment bodies should become the main bodies of management and provision of services in the field of land relations. In turn, state executive bodies will have the functions of generalisation, monitoring compliance with the rule of law upon local self-government bodies exercising their powers.

Thus, local self-government is close to the population, to its problems and needs; therefore, control over land use by local self-government is more effective, provided that local specifics and features of state regulation are considered. Considering the movement for the creation of a "Europe of Regions", the main goals and objectives of the establishment and development of the land relations management system at the municipal level should include improvement of the interaction between territorial public administration bodies and local selfgovernment bodies; provision of the necessary regulations to address issues of land relations management at the municipal level, within the framework of the established powers; prevention of speculative operations with land plots; compliance with the competence of each land relations management body; application of a set of administrative, organisational, economic, and legal forms and methods of land relations management by public administration and local self-government bodies to expand residents' access to the implementation of ownership rights to land plots.

\section{REFERENCES}

Aytkhozhaeva, G. 2018. International experience of state management of agricultural lands. World Science, 2: $14-16$.

Ignatenko, I. 2018. Decentralization of the powers of local councils in the sphere of land relations. Journal of Geography, Politics and Society, 8.

Kalogianni, E., P. van Oosterom, E. Dimopoulou and C. Lemmen. 2020. 3D Land Administration: A Review and a Future Vision in the Context of the Spatial Development Lifecycle. ISPRS International Journal of Geo-Information, 9: 107.

Konstantinova, E. 2015. Improving the efficiency of land management in municipalities. Bulletin of the Volga Academy of Civil Service, 1: 17-22.

Kravchenko, T. A. 2015. Self-government control in the field of land relations in Ukraine: The current state and ways to improve. Theory and Practice of Public Administration and Local Self-government, 1.

Kurylyak, M. 2018. Evolyutsiya kontseptsiyi «Yevropy 
rehioniv» u ramkakh rehionalnoyi polityky YES [Evolution of the concept of" Europe of the Regions" within the framework of the EU regional policy]. Kyiv, Ekonomichnyy visnyk Donbasu, 2: 60-67.

Kuz, O. M. 2019. Europe of regions" as an identical project. In M. P. Trebin (Ed.), Political and legal mentality of Ukrainian society in terms of European integration. Pravo, Kharkiv, pp. 149-65.

Kyrychenko, Y. 2020. Powers of local governments in the field of land relations. Scientific Notes of TNU named after V.I. Vernadskoho, 4: 134-139.

Lamert, D. A. 2014. Systems for management and evaluation of land resources in developed countries. In Interexpo GEO-Siberia. SGGA, Novosibirsk, pp. 3-10.

Miroshnichenko, A. and K. Marusenko. 2009. Scientific and practical commentary to the Land code of Ukraine. Pravova Yednist, Kyiv.

Monastyrskyy, H. L. 2002. Functions and powers of local governments in the field of economic and social development of rural settlements and problems of their implementation. Regional Aspects of Development and Location of Productive Forces of Ukraine, 7: 227-232.

Plotnikova, Y. I. 2017. Legal regulation of land fees in Ukraine. Institute of Legislation of the Verkhovna Rada of Ukraine, Kyiv.
Rizokulov, T. and A. Akbarzoda. 2020. Management of agricultural land resources in the regions: Foreign experience. Bulletin of TSUPBP, 2: 22-30.

Ruge, K. and K. Ritgen. 2021. Local self-government and administration. In S. Kuhlmann, I. Proeller, D. Schimanke and J. Ziekow (Eds.), Public Administration in Germany. Governance and Public Management. Springer, Cham, pp. 123-41.

Samorodov, A. S. 2016. Peculiarities of delimitation of powers in the field of land relations between local state administrations and local self-government bodies. Law and Innovation, 3: 79-86.

Shulha, M. V. and I. V. Ihnatenko. 2016. Organizational and legal support of land management within settlements. Journal of the National University "Ostroh Academy, 2: 1-9.

Slipetska, Y. 2015. From Europe of states to Europe of regions: Transformation of the idea of state sovereignty. Faces, 1: 69-73.

Strokan, V. 2009. Management of land relations in the system of local self-government: methodological aspect. Public Administration and Local Selfgovernment, 4: 272-278.

Strokan, V. 2010. Legal principles of regulation of land relations by local councils. http://www.dbuapa.dp.ua/zbirnik/201002/10svipzv.pdf.

Publisher's note: EScience Press remains neutral with regard to jurisdictional claims in published maps and institutional affiliations.

Open Access This article is licensed under a Creative Commons Attribution 4.0 International License, which permits use, sharing, adaptation, distribution and reproduction in any medium or format, as long as you give appropriate credit to the original author(s) and the source, provide a link to the Creative Commons license and indicate if changes were made. The images or other third-party material in this article are included in the article's Creative Commons license, unless indicated otherwise in a credit line to the material. If material is not included in the article's Creative Commons license and your intended use is not permitted by statutory regulation or exceeds the permitted use, you will need to obtain permission directly from the copyright holder. To view a copy of this license, visit http://creativecommons.org/licenses/by/4.0/. 